\title{
Economic Governance of Property Rights: comparative analysis on the collection of royalties in genetically modified soybean seeds ${ }^{1}$
}

\author{
Guilherme Fowler de Avila Monteiro² e Decio Zylbersztajn ${ }^{3}$
}

\begin{abstract}
This paper examines the governance of property rights on genetically modified (GM) soybean seeds. Specifically, the article undertakes a comparative analysis on the collection of royalties in GM soybean seeds in the U.S. and Brazil. For each country, the authors describe the regulatory framework governing the protection of biotechnology innovations in agriculture and investigate the mechanisms of royalty collection in GM soybean seeds. The paper also offers econometric evidence linking the capture of value on biotech innovations and the protection mechanisms deployed by biotech firms. The results suggest that, subject to the institutional environment, firms may choose to transact a GM attribute separated from the seed, building specialized governance structures framed around the genetic attribute and not around the seed as a whole.
\end{abstract}

Key-words: GM seed, royalty collection, property rights, governance mechanism.

Resumo: Este artigo examina a governança de direitos de propriedade em sementes transgênicas de soja. Especificamente, o estudo empreende uma análise comparativa sobre a cobrança de royalties em sementes transgênicas de soja nos EUA e no Brasil. Para cada país, os autores descrevem a estrutura regulatória que rege a proteção de inovações biotecnológicas na agricultura e investigam os mecanismos de cobrança de royalties em sementes transgênicas de soja. O artigo também examina evidências econométricas que relacionam a captura de valor sobre inovações biotecnológicas e os mecanismos de proteção utilizados por firmas de biotecnologia. Os resultados sugerem que, com base no ambiente institucional, uma firma pode optar por transacionar um atributo transgênico separado da semente, estabelecendo estruturas especializadas de governança que se emolduram em torno do atributo e não da semente em si.

Palavras-chaves: semente transgênica, cobrança de royalty, direitos de propriedade, mecanismo de governança.

Classificação JEL: D23, L22.

\footnotetext{
1 A first version of this paper was presented at the $15^{\text {th }}$ Annual Conference of the International Society for New Institutional Economics (Isnie) at Stanford University, California, U.S., June 2011. The authors appreciate the comments of Yoram Barzel, Elizabeth M. M. Q. Farina, Paulo Furquim de Azevedo, Sergio Lazzarini, Ana Célia Castro and Maria Sylvia M. Saes. All errors and omissions remain our responsibility.

2 Professor, Insper Institute of Education and Research. E-mail: guilhermefam@insper.edu.br

3 Full Professor, University of São Paulo. E-mail: dezylber@usp.br
} 


\section{Introduction}

The development of biogenetics has introduced a new competitive paradigm in the seed sector. Any seed may be viewed as a technology vector composed of different characteristics, being the GM seed a specific case where one or more attributes are not normally attainable by the species under natural conditions. Nowadays one can think of a GM seed that is simultaneously tolerant to a particular pesticide, resistant to certain types of pest and filled with specific nutritional attributes. Since the genetic traits that produce each of these characteristics may result from R\&D efforts made by different firms, the seed plays the role of a platform that matches interests of multiple players namely a biotech company - or group of companies and their customers, the farmers and the food consumers.

The first GM soybean seed marketed in Brazil in the 1990s/2000s incorporates the genetic trait that creates tolerance to the herbicide Roundup, whose active ingredient is glyphosate ${ }^{4}$. Value is

\footnotetext{
4 The soybean tolerant to glyphosate (RR soybean) allows the application of glyphosate for most of the harvest's life cycle. The impact of this innovation should be noted: before the advent of RR soybeans the farmer could only use glyphosate before the germination of the soybean plant, using other kinds of herbicides after its germination (post-emergent herbicides). Because RR soybean is tolerant to glyphosate, post-emergent herbicides can be replaced by the glyphosate. Accordingly, the RR soybean seed is complementary to the glyphosate and the bundle composed of RR soybean seed and glyphosate is a substitute to the bundle composed of conventional seed and post-emergent herbicides.
}

added with the adoption of GM soybean seeds based on the reduction in production costs - due to lower consumption of agrochemicals - and the small price difference between GM soybeans and conventional ones. On the other hand, the use of GM seeds requires paying royalties to Monsanto, the company that owns the technology and captures part of the value ${ }^{5}$.

Generally speaking, although royalties constitute the return associated to the innovation, it is quite common for innovators to lament the fact that imitators have profited more from the innovation than the firm that made the development effort (Teece, 1986). In the case of soybeans, the existence of selfreproducibility - i.e., transmission of genetic traits between generations ${ }^{6}$ - makes this issue even more emblematic because farmers can potentially reuse a soybean grain as seed for future seasons. As the soybean grain contains the genetic innovation and it can be used as a seed, the self-reproducibility makes the cost of capture of property rights on biotechnology innovations greatly reduced. Farmers capture property rights through the reuse of a grain crop as seed for the next season or the purchase of brown-bagged seeds.

5 The impacts of adoption of GM seeds on farmers' decisions and costs have been studied by Alexander et al. (2003) and Alston and Marra (2003)

6 Seeds characterized by self-reproducibility are called nonhybrid seeds. On the other hand, hybrid seeds are those in which transfer of genetic traits to future generations does not occur or occurs only in a limited way. 
The possibility of capture of property rights reduces the ability of biotech firms in appropriating the value generated by the biotechnology innovation. Accordingly, firms undertake protection. The basic hypothesis of this paper is that such efforts vary depending on the institutional environment. The current paper examines the governance of property rights on GM soybean seeds in different contexts. Specifically, the article undertakes a comparative analysis on the collection of royalties in GM soybean seeds in the U.S. and Brazil. For each country, we describe the regulatory framework governing the protection of biotechnology innovations in agriculture and investigate the strategies for protection of property rights in GM soybean seeds. The paper also provides econometric evidence linking the capture of property rights on biotech innovations in GM soybean seeds by farmers and the protection mechanisms deployed by biotech firms. The results suggest that, subject to the institutional environment, the firm may choose to transact the GM attribute apart from the seed, building governance structures that frame around the attribute and not around the seed as a whole. These results have interesting implications for the analysis of complex assets since they broaden the analytical framework that is usually applied to the study of governance structures.

The paper is divided into four parts besides this introduction. The next section briefly discusses the received knowledge in relation to biotechnology innovations in agriculture. Section 3 undertakes a comparative institutional analysis on the collection of royalties in GM soybean seeds in the U.S. and Brazil. Section 4 then provides econometric evidence that furthers the comparative analysis. Section 5 presents the conclusions.

\section{Knowledge received}

As outlined by Zylbersztajn et al. (2007), the literature on property rights in biotechnology innovations is profuse. Lesser (1998), for instance, explored the effects of property rights on agricultural industry structure. Alston and Venner (2000) studied the effects of plant variety protection law on research investments. Kesan and Gallo (2005) investigated the relationship between property rights and the firms' incentives to invest in seed varieties. In general, this literature is built on an implicit assumption: a strong institutional environment is a necessary condition for profitability in the agricultural biotechnology industry. As a corollary one may state that, due to the existence of self-reproducibility, the solution to the problem of appropriating value in soybean seeds requires the existence of a strong legal system that enforces protection of property rights on genetic innovations even after the marketing of the seed ${ }^{7}$.

Yet, recent studies find evidence that the operation of the market for GM soybean seeds can occur even under weak property rights, suggesting that strong regimes of intellectual property protection are not a necessary condition for the emergence of biotech firms. Wright and Pardey (2006), for instance, note that the rapid dissemination and adaptation of genetically modified seeds have taken place in developing countries even before the effectively adoption of intellectual property protection regimes.

In another study, Goldsmith et al. (2006) apply a critical case study approach to PioneerArgentina and test the arguments traditionally associated with the impact of weak systems of property rights on the seed market. The results suggest the existence of an interrelationship between the homogeneity of product demand and the protection of intellectual property rights. Overall, the firm manages its supply of soybean seeds in order to maximize profits in a secondbest world through the minimization of costs and the complementarities between soybean and corn.

Enders and Goldsmith (2007), in turn, argue that biotech companies can achieve profitability in weak institutional environments

7 Kesan and Gallo (2005), for instance, assume that the protection afforded by a patent is sufficient to mitigate the capture of value in non-hybrid seeds. 
if they adopt alternative strategies with respect to monopolistic pricing. The authors analyze the options for maximizing profits of U.S. biotech firms which operate in the relatively weak institutional environment of Argentina. Enders and Goldsmith (2007) identify three strategies: (i) to focus efforts in lobbying to improve intellectual property protection before entering the market. But, in the meantime, the biotech firm fails to profit from innovation, losing the opportunity to capture a market share; (ii) to enter the market using the traditional business model based on the institutional environment in the U.S. In this case, however, complaints about the abuse of property rights may encounter a "deaf ears" by the national authorities; or (iii) to develop an alternative strategy which incorporates the heterogeneity of institutional and business opportunities (second best strategy). The authors discuss the strategies of dynamic pricing 8 , tying and the application of genetic technologies of use restriction (i.e., introduction of genes that promote the sterility of the plant).

As a general rule, the above studies suggest that the appropriation of value on biotech innovations in GM soybean seeds is not irreversibly tied to the existence of a strong institutional environment. Goldsmith et al. (2006) and Enders and Goldsmith (2007) discuss this issue in terms of strategic choices within a North/South (U.S./Argentina) debate. While this dichotomy broadens the analytical perspectives commonly associated with the analysis of property rights in GM soybeans, in this paper we argue that the value of the U.S./Argentina debate is limited. Specifically, Goldsmith et al. (2006) and Enders and Goldsmith (2007) do not consider the existence in Brazil of a more complex scheme of collecting royalties in GM seeds.

In order to perform the analysis, the current paper examines the collection of royalties on GM technology in Brazil, highlighting its difference

8 Dynamic pricing strategy refers to the condition in which the biotech firm sets a high price in the first period of commercialization of a new GM seed, reducing the price in subsequent periods. with the U.S. case. Particularly, the article contrasts the collection of royalties in GM soybean seeds in the U.S. and Brazil taking into account a specific GM attribute (tolerance to glyphosate). The next section presents a historical analysis of property rights on plants in the U.S. and Brazil, and investigates the economic rationale that guides the collection of royalties on GM soybean seeds in each country. Section 4 then provides econometric evidence linking the capture of property rights in GM soybean seeds by farmers and the protection mechanisms deployed by biotech firms.

\section{Comparative institutional analysis}

This section conducts a comparative institutional analysis of the U.S. and Brazil. For each country, we describe the regulatory framework governing the protection of biotechnology innovations in agriculture and investigate the strategies of protecting property rights in GM soybean seeds.

\subsection{U.S.}

The U.S. through the enactment of the Plant Patent Act (PPA) in 1930, was the first country to offer a specific intellectual protection for plants. The act allows the provision of patents for new varieties of asexually reproduced plants (except tubers). Under the legislation, breeders have the exclusive rights to reproduce, sell and use the patented plant and its progeny for a limited period of time.

In 1970 intellectual property protection was extended to sexually reproduced plant varieties through the enactment of the Plant Variety Protection Act (PVPA). The PVPA states that plant varieties that meet the criteria of novelty, distinctness, uniformity, and stability ${ }^{9}$ become

\footnotetext{
9 These criteria aim to ensure that the new plant is characterized by a progeny having the same characteristics as the original plants. Note that these criteria are expendable in the case of asexually reproduced plants because in this case the original genetic material is transmitted directly to future generations.
} 
eligible to receive a Plant Variety Protection Certificate through which the breeders' rights are safeguarded. Originally the PVPA allowed the farmers to save and negotiate seeds with other parties. This configuration lasted until 1994 when an amendment to the act removed the right of farmers to sell saved seeds provided that the plant is protected by a Certificate. The amendment, however, upheld the right of farmers saving seed for their own use (farmers' exception).

In the 1980s an important change took place when the granting of utility patents for firms in the biotechnology sector became possible ${ }^{10}$, extending patent protection for specific genetic traits and biotechnology tools. Nowadays a GM seed has three components capable of patent protection: (i) the plant germplasm (i.e., the seed itself), (ii) the sequences of genes or genetic traits that result in a specific, external change in a given organism, and (iii) the research tools necessary for incorporating the new genetic trait in the plant cell (UNCTAD, 2006). The granting of utility patents for biotech firms is relevant to the extent that the seed may be understood as a platform composed of different attributes which result from R\&D efforts made by different firms. Currently a single seed can tie up a number of patents each of which protects a specific attribute.

It is worth noting, however, that the granting of a patent on a genetic trait is only the first step in the effort to protect property rights. Because soybean is characterized by self-reproducibility, users' cost of capturing property rights of technology innovations is small. Farmers capture rights by reusing the grain crop as seed for the next season or by purchasing brown-bagged seeds. In the face of this problem, the U.S. biotech firms structure their protection efforts around

\footnotetext{
10 The grant of utility patents for biotech firms dates back to two different moments. In "Diamond vs. Chakrabarty" (1980), the Supreme Court concluded that a particular bacterium generated by genetic engineering could be patented because it represented the result of human research and not the discovery of a "natural species". In "J.E.M vs. Ag. Supply Pioneer Hi-Breed International" (2001), the same logic was applied to the case of a GM plant, resulting in the extension of patent protection for plants obtained by genetic engineering.
}

the establishment of contracts in the form of technology agreements and the use of the legal system to enforce them.

Technology agreements are used by most biotech firms ${ }^{11}$. In general, each purchasing of GM soybean seed is under a contract that limits the use of the seed to a single crop and restricts $^{12}$ the saving of the harvest for future planting. Contracts stipulate prices, agronomic recommendations, penalties, and incentives to a particular culture or seed. In most agreements, the companies spell out the record numbers of their patents and the laws that ensure its protection. The agreement provides a limited use license which means that the firm allows the use of the gene by the farmer, but does not hand over its property to him.

In the specific case of GM soybean seeds commercialized by Monsanto, the agreement makes it easy for the firm to investigate the farmer's activities. It allows Monsanto to study information collected by the Farm Service Agency (FSA) for any area cultivated by the farmer, including the analysis of aerial photographs and receipts for purchase of seeds and agricultural chemicals. Access to such information helps Monsanto to determine how many bags of seed a farmer has purchased and how many acres of land were planted with a particular type of culture (CFS, 2005). The agreement also contains a provision that allows Monsanto to examine and copy any records and receipts that may be relevant for monitoring the performance of the farmer.

It is interesting to note that the provisions of the technology agreements are not free of tension. UNCTAD (2006), for instance, identifies three points of dispute between biotech companies and farmers: the principle of exhaustion, the extension of the scope of intellectual protection,

\footnotetext{
11 Maxwell et al. (2004) present a summary of the main features of the technology agreements used by leading companies in the agrobiotechnology field.

12 In some countries farmers can save its own seeds for use but not for sale. Therefore the contract is more restrictive than the law.
} 
and the inconsistency between legal rules. In what follows, we briefly describe each of these elements ${ }^{13}$.

Most schemes of intellectual property protection include a general principle called the "doctrine of exhaustion for sale" or "doctrine of first sale". According to this principle an intellectual property right is typically exhausted by the first sale or the marketing of the assets subject to protection. Based on this principle, American farmers argue that biotech companies lose control over their genetic traits when selling the GM seeds, making invalid any contractual restriction on the act of saving seeds. The courts, however, state that the general rules of patent exhaustion do not apply in these cases because the transaction is governed by a technology agreement through which the biotech firm allows the farmer's use of the gene, but does not give it to him.

Another line of reasoning maintains that biotech firms, by means of the restrictions imposed by licensing agreements, are capable of expanding the scope of patent protection. The point is that although the company holds the exclusive right to a particular genetic trait, it cannot regulate other features of the seed. However, the licensing agreement actually restricts the use not only of the genetic trait originally protected, but also of the germplasm (i.e., the seed itself). Once more, the argument has been rejected by the courts. In Pioneer vs. Ottawa (2003) ${ }^{14}$ the court concluded that a restriction against resale of patented seed represents an assertion of exclusive rights granted by the patent law and not an attempt to increase the scope of the patent.

Finally, restrictions associated with licensing patents may contravene the provisions of the Plant Variety Protection Act. In particular, restrictions on saving seeds conflict with the farmers' exception. In this respect, the Federal

13 The description below is based on Unctad (2006, p. 20).

14 Pioneer Hi-Bred Int'l, Inc. v. Ottawa Plant Food, Inc., 283 F. Supp. 2d 1018, 1031-33 (ND Iowa 2003).
Circuit ${ }^{15}$ sustained that patent owners right to prohibit the act of saved seeds even where such restrictions contradict some aspects of the PVPA.

The discussion above tells us that the courts have consistently upheld biotech firms' property rights. This finding highlights the second element that supports the protection of economic rights in the US: the use of the legal system.

If technology conditions are such that the cost of capture of property rights is sufficiently high, a law favorable to biotech firms - supported by an active, stable judicial system - is expected to reduce firms' protection cost. Given the high cost of capture and the effectiveness of the judiciary, capture attempts occur less frequently and thus less protection efforts is required. Nonetheless, since the cost of capture of property rights on GM innovations in soybeans is small, biotech companies must use more complex schemes of monitoring and enforcing technology agreements. Monsanto, for instance, created a department composed of 75 officials that consumes US\$ 10 million annually whose sole purpose is to ensure the protection of property rights (ENDERS and GOLDSMITH, 2007). This is interesting because it reveals that the recourse to the legal system neither represents a set of fuzzy legal claims, nor takes the form of an omnipresent threat that, by itself, automatically reduces the intensity of the capture attempts. The protection of property rights requires an organizational structure.

In the case of Monsanto, the operation of such organizational structure has resulted in the filing from 1997 to 2007of 112 legal claims involving 372 farmers and 49 small associations ${ }^{16}$. As shown in Table 1, approximately $51 \%$ of the legal claims resulted in the recognition of damage to Monsanto, $21 \%$ resulted in agreements, $12 \%$ were rejected (no indication whether any damage was awarded) and 16\% had not been

\footnotetext{
15 McFarling I, 302 F2d 1291 (Fed Cir 2002); McFarling II, 363 F3d 1336 (Fed Cir 2004).

16 Data refer to legal claims issued by Monsanto against US farmers under the claim of saving seeds and/or purchasing seeds from unauthorized resellers (brown bagging). Legal claims are not only related to soybean seeds, including also canola and cotton seeds.
} 
Table 1. Lawsuits filed by Monsanto against farmers under the claim of saving seed, U.S., 1997-2007

\begin{tabular}{lcc}
\hline & Number of lawsuits & $\%$ \\
\hline Award of damage to Monsanto & 57 & 50,9 \\
Agreement (confidential) & 24 & 21,4 \\
Dismissal (no indication of award of damage) & 13 & 11,6 \\
Not concluded (till October /2007) & 18 & 16,1 \\
Total & 112 & 100,0 \\
\hline
\end{tabular}

Source: Center for Food Safety (CFS 2007).

completed. In the case of conviction of the farmer (i.e., recognition of damage to Monsanto), compensation ranged from US $\$ 5,000.00$ to US\$ 3 million. The average penalty was approximately US\$ 385,000.00 (CFS 2007).

\subsection{Brazil}

It was only in the second half of the 1990s that Brazil began to design a regulatory framework for granting property rights to plants and regulating genetically modified organisms (GMO). The first law was passed in 1995, being known as the "First Biosafety Law" (Law no 8,974/95). This law in conjunction with Decree 1,752/95 created the National Technical Committee for Biosafety (CTNBio) to be in charge of passing judgment upon proceedings related to GMO activities.

One year after the creation of CTNBio the patenting of GM organisms was enabled by the Law of Industrial Protection (Law no 9.279/96) passed in 1996. According to the law, the whole or part of GM organisms are patentable provided that it meets the principle of novelty, results from an inventive activity, has some industrial application, and does not represent a mere discovery ${ }^{17}$. In general, a biotech firm in Brazil may gain a patent on a genetic trait and/or a biotechnology tool which points out that the Law of Industrial Protection is similar to the concept of utility patent.

In 1997 Brazil became a member of the International Union for Protection of New

\footnotetext{
17 Discovery means the introduction in a particular location of plants collected in other locations.
}

Varieties of Plants (Upov) ${ }^{18}$. In the same year, the Law of Cultivar Protection (Law no. 9,457/97) was approved. This law is similar to the Plant Variety Protection Act in that it benefits the breeder/ developer through the recognition of ownership rights related to new plant varieties. The law not only establishes the right of temporary monopoly on the commercial reproduction of new plant varieties, but it also grants small farmers the right to save and exchange seeds (farmers' exception).

In view of the above regulatory framework Monsanto obtained in 1998 CTNBio's permission to market GM soybean seeds tolerant to glyphosate ${ }^{19}$. But, the authorization was revoked by the judiciary in 1999 in the face of a legal claim filed by the Brazilian Institute for Consumer Protection (Idec), a nongovernmental organization. Firstly, Idec claimed that the authorization granted to Monsanto was groundless because CTNBio supposedly failed to request an environmental impact assessment (EIA) specific to the Brazilian conditions ${ }^{20}$. Secondly, and more importantly, Idec claimed that the power originally conferred to CTNBio with the purpose of authorizing the marketing of GM seeds was in contradiction to the responsibilities of local governments and municipalities to regulate environmental issues. As a result, the

18 The Upov (www.upov.int) is an international convention that establishes a multilateral agreement setting common standards for the recognition and protection of new varieties of plants.

19 It is worth noting that in Brazil, Monsanto has a patent on the technology of GM tolerance to glyphosate.

20 It was alleged that Monsanto submitted a Risk Analysis which included the examination of evidence for several countries, except Brazil. 
Graph 1. Ratio between the consumption of saved or brown-bagged seed and the total consumption of seeds (soybeans), Rio Grande do Sul, 1999-2006

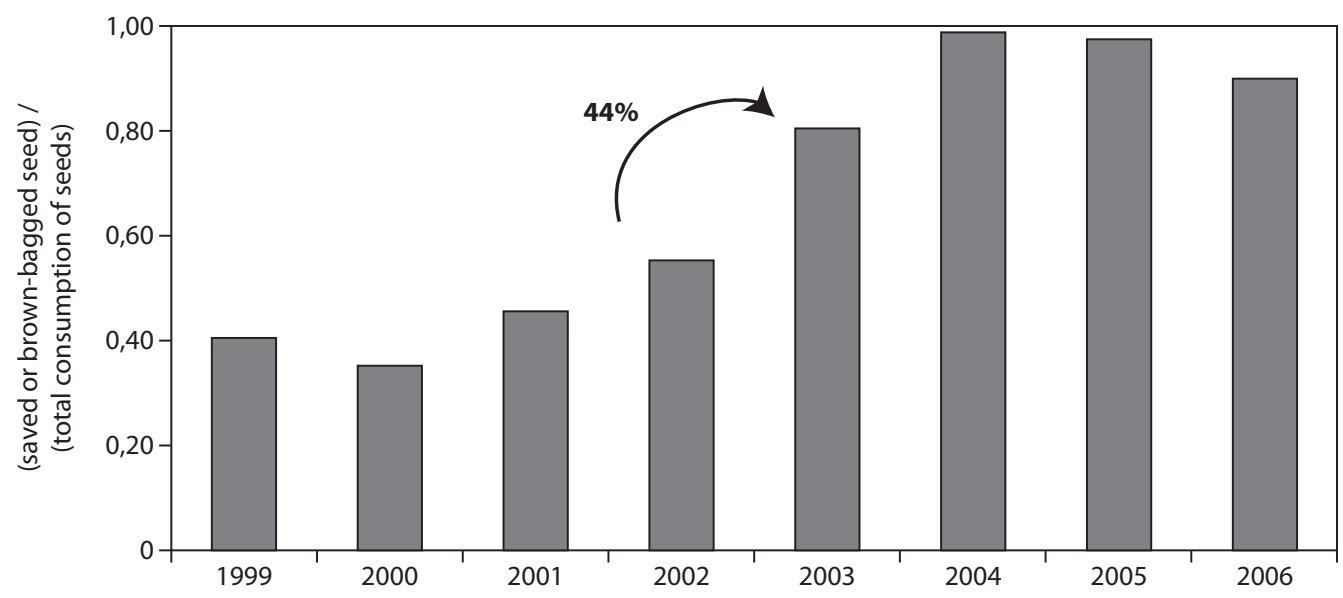

Source: Brazilian Association of Seeds and Seedlings (Abrasem) - prepared by the authors.

marketing of GM seeds was banned until the enactment of the "New Biosafety Law" (Law no $11.105 / 05)$ in 2005.

Despite the ban on planting GM seeds, farmers - especially in the southern region of Brazil have illegally adopted Monsanto's technology through the smuggling of Argentinean soybean seeds from 2003 to $2005^{21}$. As indicated in graph 1 which shows the consumption trend of saved and brown-bagged soybean seeds in the state of Rio Grande do Sul (southern region of Brazil), the year of 2003 marks an increase of $44 \%$ in the demand for the seeds.

It is interesting to note that the prohibition in domestic marketing of GM seeds along with the illegal import of seeds from Argentina restricted the property rights protection strategies available to biotech firms. There was no basis for legal action for recovery of royalties since the presence of GM seeds in the domestic market was legally prohibited. This lack of basis for royalty collection, however, did not last for long. In 2004 the Brazilian market was flooded with GM grains whose existence in the national market

21 Monsanto began the marketing of GM soybean seeds in Argentina in 1996. was not authorized. In the face of this problem, and considering the large soybean production, the Brazilian government decided to implement a series of legal measures that allowed ex-post the planting of GM seeds ${ }^{22}$. If adoption of GM seeds is legally permitted and farmers effectively adopted it, then firms may establish mechanisms for recovery of royalties (ZYLBERSZTAJN et al., 2007).

In the case of Monsanto, the collection of royalties had to cope with two aspects. On the one hand, it had to be retroactive because farmers had already harvested the GM soybeans. On the other hand, it would be based on seeds purchased on the black market. As described in figure 1, the collection of royalties was based on three components: (i) the existence of an inexpensive field test for the detection of genetic traits in soybean seeds, (ii) the design of a contract involving three parties, and (iii) the establishment of a credible threat.

\footnotetext{
22 Medidas Provisórias (provisional measures) no 113/2003, 131/2004, 223/2005.
} 
Figure 1. Mechanism of collecting royalties, Monsanto, Brazil, the southern region

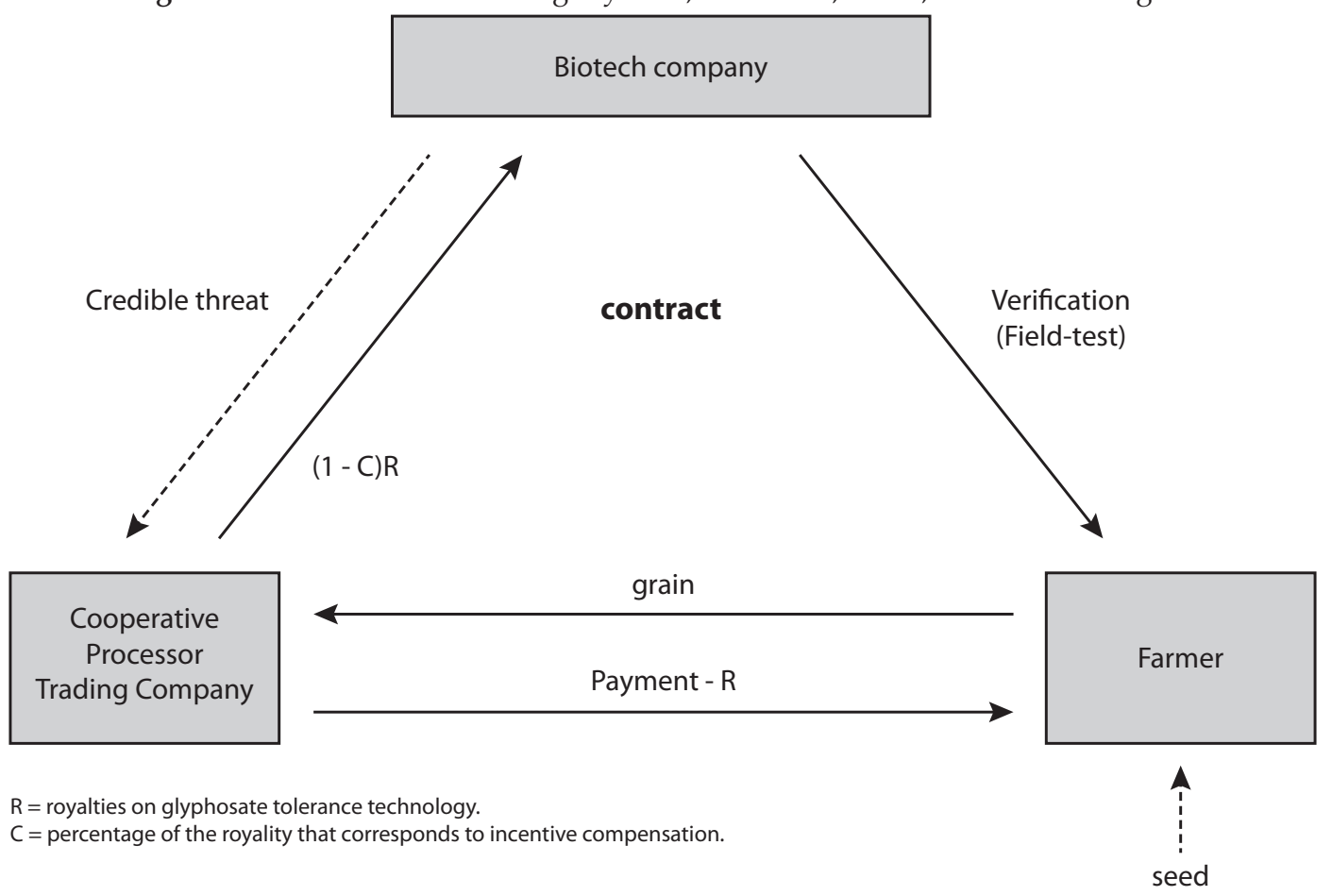

Source: Prepared by the authors.

Since farmers in the southern region of Brazil are numerous and the adoption of the technology had already occurred, Monsanto would face a high monitoring cost if it decided to negotiate individually with each farmer. However, since the harvested grains have to be transported to cooperatives, processors, and trading companies, the monitoring cost in this stage of the production chain is comparatively lower. Consequently, due to the existence of an inexpensive field test, Monsanto was able to identify the presence of the genetic trait through genetic analysis of soybean shipments carried by trucks into the cooperatives, processors, and trading companies.

Monsanto then established a difficult process with the four largest trading companies operating in the southern region of the country. The biotech firm proposed that traders collect the royalties on the genetic technology based on the ton of soybean grain delivered by farmers, keeping a percentage of the royalties as incentive compensation. Initially, the traders decided not to cooperate. Nevertheless, the resistance was offset by a credible strategic move made by Monsanto. Supported by international laws for the protection of property rights ${ }^{23}$, the company intercepted a ship in the port of Trieste, Italy, carrying a large shipment of Brazilian soybeans. For fear of exposure, the trading companies agreed to negotiate. For the same reason, cooperatives and processors also decided to collaborate with the biotech firm. As a result, Monsanto was able to structure a royalty collection scheme based on a contractual arrangement.

A contract was designed so that each farmer had the freedom to state what type of technology had been used on his property. If the farmer declared that he had used GM seeds, a charge was laid and its value was reduced from the payment made to the farmer by the cooperative, the processor, or the trading company. If the farmer did not declare the adoption of the GM

23 Brazil joined Upov in 1997. 
technology, the field test was conducted on each shipment delivered by the farmer. If the test was positive for the presence of GM seeds, the farmer had to pay a fine and bear the costs of the test. Given the widespread adoption of GM seeds and the risk of penalty, $98 \%$ of farmers in the southern region of Brazil agreed to the arrangement (ZYLBERSZTAJN et al., 2007) ${ }^{24}$.

Overall, the analysis of the mechanism of collecting royalties on GM soybean seeds in the southern region of Brazil reveals a subtle phenomenon. The property rights protection effort undertaken by the firm is based on the unbundling of the attribute (tolerance to glyphosate) from the asset (seed), outlining a particular way to negotiate about the attribute regardless of how the asset is acquired. This is relevant since the collection of royalties is based on seeds purchased in the black market. The result contrasts with the U.S. case, where all the protection effort made by Monsanto focuses on combating the saving of seeds.

Although the above argument might suggest that the strategy implemented in the southern region of Brazil is more efficient than that established in the U.S. since the firm is able to collect royalties on the technology even in the case of saved seed, it is worth noting that the contractual arrangement structured in Brazil is more complex than the filing of legal claims. The arrangement entails the coordination of multiple agents and different transactions. In fact, as soon as the problem of illegal seed acquisition became less intense, Monsanto altered its strategy of collecting royalties. This is the case of the Midwest of Brazil.

The major soybean producing states of the Midwest of Brazil are Mato Grosso do Sul (MS) and Mato Grosso (MT). Industry sources say that GM soybeans represent $80 \%$ of soybean production of Mato Grosso do Sul and $40 \%$ of soybean production

${ }^{24}$ Currently, the royalty payment is set at $2 \%$ on the value of total production. The fine was set at $\mathrm{R} \$ 150.00$ per ton. (season 2004/2005) equivalent to approximately U.S.D 53.40 per ton. of Mato Grosso ${ }^{25}$. Generally speaking, the Midwest has two distinct characteristics relative to the southern region of Brazil with regard to soybean production. Firstly, the average farm size in the Midwest is bigger than that of the south. A typical rural property in the state of Mato Grosso, for instance, has approximately 8,000 acres compared to 2,000 acres in Rio Grande do Sul (VEIGA and ANTUNIASSI, 2008). Secondly, in the Midwest the adoption of GM technology has been slower than in the south. In the south, smuggled GM seeds spread rapid due to the similarity of climate and soil between the region and Argentina. In the Midwest, rapid adoption has not occurred due to the need for adaptation of seed varieties to the "cerrado" environment. This type of environment has specific climate and soil which make the planting of a seed originally intended for Argentina far from the most favorable choice. Perhaps more importantly, the climate in the Midwest can cause deterioration of stored seed if specific conditions such as cold storage system are not met. These conditions, in turn, raise the cost of saving seeds. As noted in Table 2, after a peak of $80 \%$ in 2003 the consumption of saved and brown-bagged seeds in the state of Mato Grosso do Sul decreased faster than in the state of Rio Grande do Sul.

In the Midwest the collection of royalties from GM seeds occurs by means of payment slips which are delivered to farmers by cooperatives or dealers at the time of seed purchase. Initially, Monsanto had stipulated that the value of the royalty should be $\mathrm{R} \$ 0.88$ per kilo of seed (approximately U.S.\$ 0.38). Subsequently, the value was set at R\$ 0.50 per kilo (U.S.\$ 0.23 ). These amounts, however, were never charged. In the 2006/07 and 2007/08 seasons, when the system was effectively put into practice, the royalty paid by farmers was R\$ 0.30 per kilo of seed (U.S.\$ 0.17 ) which is equivalent to $27 \%$ of the value of

\footnotetext{
25 The discussion that follows is based on the report "Organização dos Mercados de Insumos e Relações com a Agricultura" [Organization of Input Markets and the Relationship with Agriculture] held at the request of the Brazilian National Agricultural Confederation (CNA).
} 
Table 2. Percentage of saved and brown-bagged seed in selected states of Brazil, 1999-2006

\begin{tabular}{lcc}
\hline & $\begin{array}{c}\text { Mato Grosso do Sul } \\
\text { (Midwest region) }\end{array}$ & $\begin{array}{c}\text { Rio Grande do Sul } \\
\text { (southern region) }\end{array}$ \\
\hline 1999 & 35,0 & 40,0 \\
2000 & 35,0 & 35,0 \\
2001 & 50,0 & 45,0 \\
2002 & 50,0 & 55,0 \\
2003 & 80,0 & 79,5 \\
2004 & 50,0 & 99,0 \\
2005 & 55,0 & 97,0 \\
2006 & 58,0 & 90,0 \\
\hline
\end{tabular}

Source: Brazilian Association of Seeds and Seedlings (Abrasem) - prepared by the authors.

the soybean seed bag. In the 2008/09 season, the royalty was set at $\mathrm{R} \$ 0.35$.

In the case of non-payment of the slip, under the assumption that the farmer is reported in the field test for detection of GM traits, Monsanto can charge a default rate of $2 \%$ on production. This default rate, however, is not necessarily applied to the whole production. The scheme works as follows: Each payment slip generates a certain amount of "royalty credits". When performing the field test and verifying the farmers' total production, Monsanto compares the amount of credits accumulated by the farmer and the actual level of production. If production exceeds the equivalent amount of credits, the farmer pays a fee of $2 \%$ on the excess. The logic of the scheme is simple. If the farmer has not only acquired a certain amount of GM seeds, but also used saved seeds there is an incompatibility in the harvest period between actual production and ideal production - i.e., the production obtained by the exclusive use of seeds purchased legally. It is this inconsistency that Monsanto checks ${ }^{26}$ and the rate of $2 \%$ levied on the difference between actual and ideal production.

Note that the stability of the mechanism of collecting royalties in the Midwest of Brazil is still an open question since the relationship between Monsanto and the farmers in the region is not free of tension. Industry sources say that in

${ }^{26}$ Upon completion of field tests Monsanto identifies the farmer and the amount paid in royalties. light of agronomic advances, there are soybean varieties that demand a smaller quantity of seed per acre which reduces the value that farmers are supposed to pay Monsanto and this enables Monsanto to recover royalties that are not due to it. Currently discussions are moving towards selecting the best time for collecting the royalties. Farmers suggest that royalty be charged close to the harvest period when it becomes possible to more precisely measure the effective yield of the crop.

\section{Royalty collection schemes and the farmers' reactions}

The present section aims to deepen the comparative results of the strategies of protecting property rights discussed above. It provides econometric evidence linking the capture of property rights on biotech innovations in GM soybean seeds and the protection mechanisms deployed by biotech firms. In particular, we analyze the influence of royalty collection strategies on the incentive for farmers to save or acquire brow-bagged GM soybean seeds ${ }^{27}$. In what follows we present a panel estimation to the Brazilian market of GM soybean seeds and seek similar econometric evidence for the U.S. soybean market.

\footnotetext{
27 The authors had no access to the collection of royalties by the biotechnology company.
} 


\subsection{Econometric evidence in Brazil}

In Brazil, estimations are carried out based on the use of brown-bagged and saved seeds in eight states ${ }^{28}$ between 1995 and $2008^{29}$. Data are organized as a panel. The dependent variable corresponds to the size of brow-bagged and saved soybean seed market measured as a percentage of the total market of soybean seeds ${ }^{30}$. It is noteworthy that estimates are based on aggregated data by states, since there are no available microdata. The independent variables include the region of production, the introduction of GM seeds in the country ${ }^{31}$, the changing in the institutional environment through the enactment of the New Biosafety Law in 2005, the price of certified soybean seed, the introduction of contracts in the southern region of Brazil and the issuance of payment slips in the Midwest of the country.

Generally, it is expected that the consumption of brown-bagged and saved soybean seed be greater (i) in the southern region compared to the Midwest and (ii) following the introduction of GM seeds in the country. Consumption also tends to be greater the higher the price paid for certified seeds. Particular interest is placed on analysis of the estimated coefficients for 'contracts' and 'payment slips' since it represents the protection strategy implemented by the biotech firm. The estimation also considers three control variables: the price of soybean paid to farmers, the price of glyphosate-based herbicide, and the availability of rural credit. In the model, farmers' choice is conditioned on lagged values of the prices of seeds, soybean, glyphosate, and credit amount,

${ }^{28}$ Goiás, Minas Gerais, Mato Grosso do Sul, Mato Grosso, Paraná, Rio Grande do Sul, Santa Catarina e São Paulo.

29 The time period was defined by the availability of data. A longer period of time would certainly allow stronger conclusions.

30 Due to limitations in the database, it is not possible to separate the purchase of brown-bagged seed and the consumption of saved seed. See the appendix for a description of the variables used in the estimations.

31 GM soybean seeds were actually introduced in the country in 2003 by smuggling seeds from Argentina. reasoning that the prices in the previous period affect farmers' decision today ${ }^{32}$.

In regard to the estimation method, the first two columns of Table 3 identify, respectively, fixed effects estimate and random effects estimate. When conducting the tests for the significance of fixed and random effects, one finds that both are significant (see Table 3). The Hausman test, in turn, cannot be computed due to a violation of asymptotic testing hypotheses. Since the estimates are roughly equivalent, the random effects model is more attractive. By employing a generalized least squares estimator (GLS) this model provides the best linear unbiased estimator, which is consistent and asymptotically efficient when it is assumed that the error of the regression model is uncorrelated with the independent variables (Balgati, 2005).

Regarding the residuals' variance, the results indicate the presence of strong heterogeneity among the cross-section units. In order to account for such, heterogeneity we estimate a model using the White correction (third column of Table 3). The Wooldridge test for autocorrelation, in turn, does not indicate the presence of first-order serial correlation in the panel. Nevertheless, one should be aware of the presence of specific autocorrelation within the data. The Q-test indicates first-order serial correlation for seed price and the participation of brown-bagged/ saved seeds in the states of Mato Grosso, Parana, Rio Grande do Sul and Santa Catarina.

Finally, since the number of time units in the panel is greater than the number of states, one way to test the independence between units of cross-section is the LM test developed by Breusch and Pagan (1980). As shown in Table 3, we fail to reject the null hypothesis of independence at $5 \%$ significance level. This result, however, should not be taken at face value. On the one hand, there are strong reasons to assume that the soybean market and the use of brown-bagged/saved soybean seeds are correlated between different states e.g., the effects of random shocks may affect the soybean market with no regional differences.

\footnotetext{
32 See the appendix for a description of the variables used in the estimations.
} 
On the other hand, the Breusch-Pagan LM test requires that the number of cross-section units in the panel be fixed and the time dimension to tend to infinity. The current model, however, is based on eight units of cross-section and only 14 years. Thus, Table 3 presents two GLS estimations, the first assuming independence between the units of cross-section (I) and in the second the units are contemporaneously correlated (II).

It should be emphasized that the use of GLS estimation in the current case is not free of problems. As observed by Beck and Katz (1995), the use of generalized least squares can generate upward biased estimates of standard deviation, leading to a greater likelihood of rejection of the hypothesis of insignificance of the estimated coefficients. This result derives from the fact that the ratio of the temporal dimension to the number of cross-section units in the panel is near to unity so that the estimation of the covariance matrix of contemporaneous errors is based on slightly more than three observations per estimate ${ }^{33}$. Thus, Table 3 also presents an estimation based on Prais-Winsten method. By this method one accounts for the presence of heteroscedasticity, contemporaneous correlation between cross-section units and autocorrelation AR (1) specific. The difference between GLS and the method of Prais-Winsten is that the latter is based on a specific correction for the standard errors of the ordinary least squares (OLS) estimate ${ }^{34}$.

When analyzing the results of the PraisWinsten estimation, three points should be underlined. Firstly, states in the Midwest tend to brown-bag/save on average $15 \%$ less soybean seeds compared with other Brazilian states. This result, as previously discussed, can be attributed to the soil and climate of the region which increase the cost of saving seed. Secondly, the introduction of GM technology in Brazil has increased the consumption of brown-bagged/saved soybean seed in the southern region of the country by

33 Each element of the covariance matrix of contemporary errors is estimated using an average of 2.(T/N) observations (Beck and Katz, 1995: 637). In the current case this implies 2. $(14 / 8)=3.5$ observations.

${ }^{34}$ For further details of the method see Beck and Katz (1995).
$17 \%$. This result relates to geographic conditions which facilitate the saving of seed and to the smaller size of rural properties - and consequent greater proximity between farmers - which facilitates the establishment of a black market for seeds once GM seeds have been smuggled from Argentina. Thirdly, raising the price received for soybean tends to reduce the current demand of saved seed by $0.6 \%$. The interpretation of this result may be intricate; it can be argued that the higher income generated in the previous season can encourage farmers to purchase a larger quantity of certified seeds in the current period, indicating an 'income threshold' from which the consumption of certified seeds becomes larger.

The GLS estimation (II) in accordance to the above discussion produces a larger number of significant coefficients. The estimation suggests that the introduction of GM seeds in the country also encouraged the brown-bagging/saving of seeds in the Midwest, although at a lower level (5\% in the Midwest compared with $18 \%$ in the southern region). The promulgation of the New Biosafety Law also led to an increase in market share of saved seeds, suggesting that changing the legal regime has encouraged the adoption of GM technology. Regarding glyphosate, the rise in its price indicates extra reduction in the demand for certified seeds, suggesting that farmers seek to establish a stable disbursement with the package composed of GM seed and glyphosate. These results, however, are subject to the criticism advanced by Beck and Katz (1995).

A crucial point regarding the estimations is that the variable 'contract' is non-significant in all estimated models. This result should come as no surprise since the mechanism of royalty collection in the southern region of Brazil does not depend on the acquisition of the seed. As discussed, the collection of royalties is based on seeds purchased in the black market. The variable 'payment slip', in turn, is significant and negative in the GLS model (II), suggesting that the collection scheme established in the Midwest is successful in reducing consumption by farmers of brown-bagged and saved seed. 
038 - Economic Governance of Property Rights: comparative analysis on the collection of royalties in genetically modified soybean seeds

Table 3. Brazilian Market of Soybean Seeds

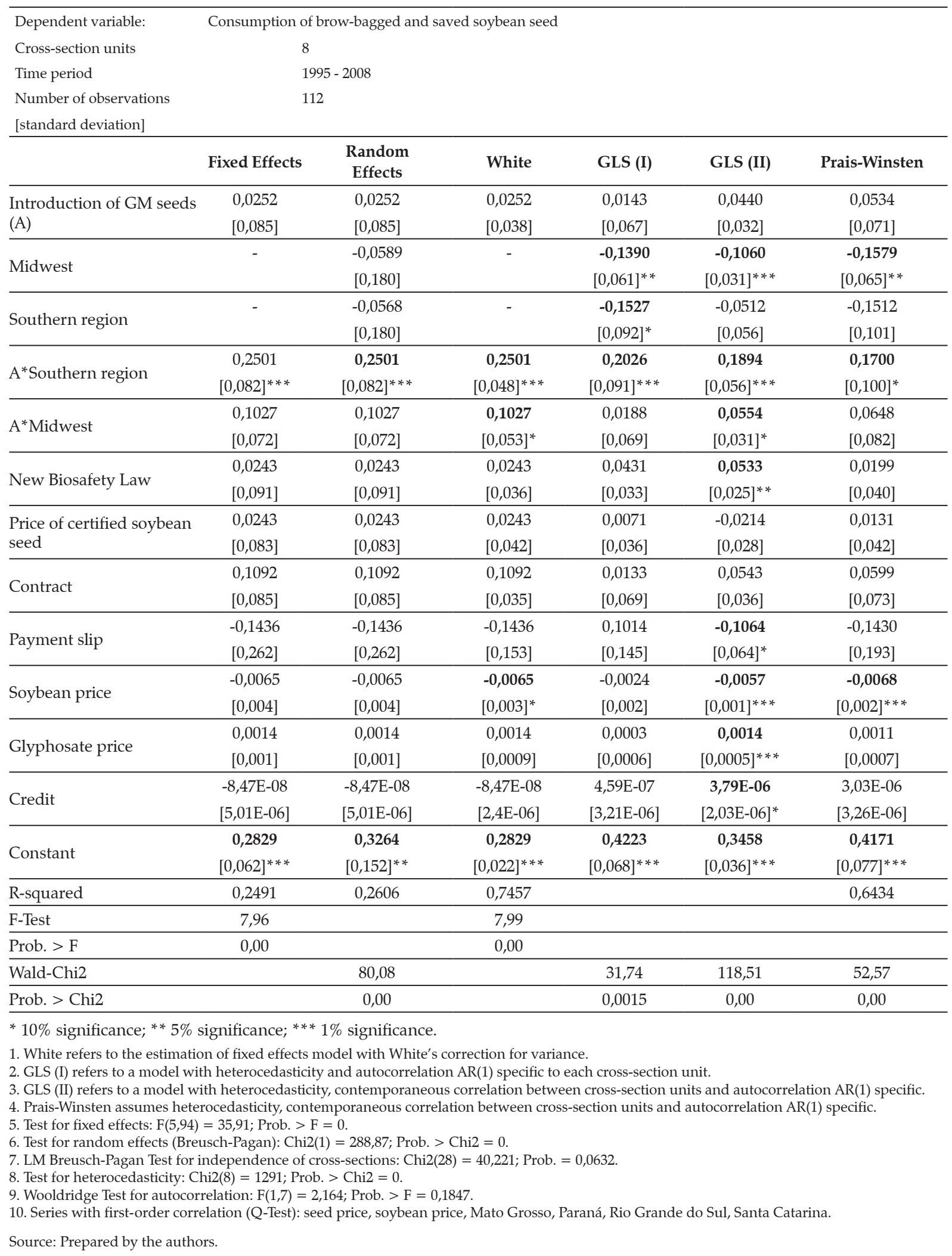


Table 4. U.S. Market of Soybean Seeds

\begin{tabular}{|c|c|c|c|c|}
\hline Dependent variable: & \multicolumn{3}{|c|}{ Consumption of brow-bagged and saved soybean seed } & \\
\hline Cross-section units & \multicolumn{3}{|c|}{14} & \\
\hline Time period & \multicolumn{3}{|c|}{ 1997-2002 (truncated in 2001) } & \\
\hline \multirow{2}{*}{$\begin{array}{l}\text { Number of observations } \\
\text { [standard deviation] }\end{array}$} & \multicolumn{2}{|c|}{70} & & \\
\hline & Fixed Effects & Random Effects & White & Prais-Winsten \\
\hline \multirow{2}{*}{ Adoption of GM technology } & $-0,1132$ & $-0,1162$ & $-0,1162$ & $-0,1244$ \\
\hline & {$[0,180]$} & {$[0,178]$} & {$[0,010]^{*}$} & {$[0,0096]^{*}$} \\
\hline \multirow{2}{*}{$\begin{array}{l}\text { State is a major producer of } \\
\text { soybeans(dummy) }\end{array}$} & - & 0,0168 & 0,0168 & 0,0231 \\
\hline & & {$[0,046]$} & {$[0,041]$} & {$[0,020]$} \\
\hline \multirow{2}{*}{$\begin{array}{l}\text { Price of certified soybean } \\
\text { seed }\end{array}$} & $-0,0098$ & $-0,0083$ & $-0,0083$ & $-0,0044$ \\
\hline & {$[0,016]$} & {$[0,016]$} & {$[0,005]^{* * *}$} & {$[0,005]$} \\
\hline \multirow{2}{*}{ Legal claim } & 0,0071 & 0,0048 & 0,0048 & $-0,0002$ \\
\hline & {$[0,007]$} & {$[0,007]$} & {$[0,006]$} & {$[0,07]$} \\
\hline \multirow{2}{*}{ Soybean price } & 0,0123 & 0,0118 & 0,0118 & 0,0106 \\
\hline & {$[0,028]$} & {$[0,028]$} & {$[0,001]^{*}$} & {$[0,002]^{*}$} \\
\hline \multirow{2}{*}{ Glyphosate price } & 0,0024 & 0,002 & 0,002 & 0,001 \\
\hline & {$[0,005]$} & {$[0,005]$} & {$[0,001]$} & {$[0,0012]$} \\
\hline \multirow{2}{*}{ Soybean subsidies } & $7,90 \mathrm{E}-05$ & $5,80 \mathrm{E}-05$ & $5,80 \mathrm{E}-05$ & $-3,67 \mathrm{E}-07$ \\
\hline & {$[1,1 \mathrm{E}-04]$} & {$[1,0 \mathrm{E}-04]$} & {$[7,6 \mathrm{E}-04]$} & {$[7,1 \mathrm{E}-05]$} \\
\hline \multirow{2}{*}{ Constant } & 0,1366 & 0,1333 & 0,1333 & 0,1410 \\
\hline & {$[0,308]$} & {$[0,306]$} & {$[0,027]^{*}$} & {$[0,011]^{*}$} \\
\hline R-squared & 0,1757 & 0,1885 & 0,1885 & 0,1971 \\
\hline F-Test & 4,38 & & & \\
\hline Prob. $>$ F & 0,00 & & & \\
\hline Wald-Chi2 & & 26,49 & 26,49 & 1510,04 \\
\hline Prob. > Chi2 & & 0,00 & 0,00 & 0,00 \\
\hline
\end{tabular}

${ }^{*} 1 \%$ significance; ${ }^{* *} 5 \%$ significance; ${ }^{* * *} 10 \%$ significance.

1. White refers to the estimation of random effects model with White's correction for variance.

2. Prais-Winsten assumes heterocedasticity and contemporaneous correlation between cross-section units.

3. Test for fixed effects: $\mathrm{F}(12,50)=4,82$; Prob. $>\mathrm{F}=0$.

4. Test for random effects (Breusch-Pagan): Chi2(1) $=22,97$; Prob. $>$ Chi2 $=0$.

5. Hausman Test: Chi2(6) =0,76; Prob. $>$ Chi2 $=0,9932$.

6. Pesaran Test for independence of cross-sections: Pesaran $=-0,978$; Prob. $=0,3282$.

7. Test for heterocedasticity: Chi2(14) $=603,73$; Prob. $>$ Chi2 $=0$.

8. Wooldridge Test for autocorrelation: $\mathrm{F}(1,13)=3,653$; Prob. $>\mathrm{F}=0,0783$.

9. No series has first-order correlation (Q-Test).

Source: Prepared by the authors.

\subsection{Econometric evidence in the U.S.}

In order to build a comparative analysis for the U.S. we seek similar econometric evidence for the U.S. soybean market. In the American case, our estimates are based on the participation of brown-bagged/ saved seed market in 14 states $^{35}$ between 1997 and 2002. A regression model similar to that shown

35 Arkansas, Illinois, Indiana, Iowa, Kansas, Kentucky, Michigan, Mississipi, Missouri, Nebraska, North Carolina, Ohio, South Dakota, Tennessee. above is estimated. However, unlike the variables 'contract' and 'payment slip' the estimation uses the number of legal claims brought by Monsanto against farmers. In particular, we analyze the cumulative size of legal claims. This variable not only represents the protection strategy of the biotech company, but also seeks to capture the effect of legal action over time ${ }^{36}$.

\footnotetext{
36 See the appendix.
} 
Similarly to the Brazilian case, the first two columns of Table 4 present the estimates of fixed effects and random effects for the U.S. soybean seed market. Although both fixed and random effects are significant, the Hausman test indicates that the second estimator is consistent. Additionally, heteroscedasticity is present and the first-order autocorrelation in the panel is absent. This combination suggests the estimation of a robust model presented in the third column of Table 4. Regarding the independence of crosssectional units, since the number of states in the panel is larger than the number of time units, the Breusch-Pagan LM test loses its effectiveness and one should estimate a Pesaran test. The test result, as shown in Table 4, suggests that cross-sectional units are independent. Once again, we do not take this result face value. Thus, we also estimate a model using the Prais-Winsten method ${ }^{37}$.

Overall, White and Prais-Winsten estimates give similar results. The market share of brownbagged and saved seeds is explained mainly by the price of soybean and the rate of adoption of GM technology. Regarding the price of soybean, it is interesting to note that the result to the U.S. market is the opposite of that obtained for the Brazilian market, i.e., raising the price of soybean tends to increase the farmers' current demand of saved seed in approximately $1 \%$. One may speculate that the higher income generated in the current season encourages farmers to save seeds as a safeguard for future rise in the seed price.

The main result of the estimations, however, is that the sign of the correlation of rate of adoption of GM technology with market share of brownbagged/saved seeds is negative. This result is not surprising when one notes that the estimation directly addresses only one of the two elements that form the basis of the protection strategy of biotech companies in the U.S. market, namely the appeal to the legal system. The estimate does not explicitly take into account the formation of technology agreements contracts. Nonetheless,

\footnotetext{
37 Since the number of cross-section units is larger than the number of time units, the GLS estimation does not generate consistent results (Beck and Katz, 1995).
}

since each transaction for the sale of GM seeds involves the establishment of a contract, the adoption rate of GM seeds is a natural proxy for the adoption of such agreements. In that sense, what the estimates reveal is that the formation of contracts is one explanation for the reduction of brown-bagging/saving of soybean seeds, suggesting that the U.S. institutional environment is strong enough to create incentives for compliance with the terms of the contracts. What the estimates do not measure is the second order effect of the legal claims on the fulfillment of contracts. This aspect may be potentially important.

\section{Conclusions}

Property rights over genetic innovations in soybean seeds are subject to capture because the biological characteristics of the seed - i.e., selfreproducibility - place such innovations in the public domain, creating the possibility of capture of value. As a result, firms undertake protection efforts by means of developing organizational arrangements in order to minimize the capture of value. The above discussion suggests that such organizational arrangements are dependent on the institutional environment in which the purchasing of the seed occurs.

In the U.S. where the institutional environment is strong, the firm undertakes protection efforts based on the establishment of technology licensing contracts along with the use of the legal system. In general, econometric evidence suggests that the establishment of contracts represents a fundamental component of the strategy of protecting property rights. The analysis also suggests that the use of the legal system does not assume the form of an omnipresent threat that, by itself, automatically reduces the intensity of capture attempts. As shown, the protection of property rights requires a specialized organizational structure.

In Brazil, the firm holding the technology found a way to collect royalties even in a situation where the institutional environment is weak. 
The solution involves two distinct governance structures: the introduction of contracts in the southern region of Brazil and the issuance of payment slips in the Midwest of the country. The similarities between these governance structures are that (i) the firm ensures its rights by exercising a deliberate, active monitoring role and (ii) the attribute "tolerance to glyphosate" is transacted in separate from the asset (seed) ${ }^{38}$. The unbundling of the attribute from the asset indicates that the firm prefers to internalize the allocation function that is usually associated to the market. Accordingly, a firm's efforts of protecting property rights involve the building of governance structures that are organized around the attribute and not of the asset. This is relevant in that the institutional environment encourages the firm to directly handle the transaction of the attribute.

The combination of the above arguments suggest a more general proposition: when the transaction of the attribute is disconnected from the transaction of the asset, the firm loses in economies of scale ${ }^{39}$ but gains in efficiency of the protection of property rights, given the possibility of capture of these rights and the quality of the institutional environment. This proposition has interesting implications to the analysis of complex assets since it broaden the analytical framework that is usually applied to the study of governance structures. Under the lens of this expanded framework, governance structures emerge with the deliberate purpose of protecting property rights associated with certain attributes of an asset, while disregarding other less valuable attributes. We should consider that the more genes are marketed for specific crops, each with different ownership, the more complex the protection mechanisms will be. Future research should seek to deepen this subject, both theoretically and empirically.

38 In the Midwest of Brazil the value of the payment slip is not included in the price of the GM seed.

39 The greater the number of attributes commercialized within a given asset (e.g. seed), the lower the unit cost of transacting each attribute.

\section{References}

ALEXANDER, C., CORNEJO, J. F., GOODHUE, R. E.. Effects of the GM controversy on IOWA corn-soybean farmers' acreage allocation decisions. Journal of Agricultural and Resource Economics 28(3), pp. 580-595, 2003.

ALSTON, J. M., MARRA, M. An ex-ante analysis of the benefits from the adoption of corn rootworm resistant, transgenic corn technology. Paper presented at the GENERAL MEETING OF THE AU.S.TRALIAN AGRICULTURAL AND RESOURCE ECONOMICS SOCIETY, 2003.

ALSTON, J. M., VENNER, R. The effects of the U.S. Plant Variety Protection Act on wheat genetic improvement. Research Policy 31, pp. 527-542, 2002.

BALGATI, B. H. Econometric Analysis of Panel Data. John Wiley \& Sons Ltd, England, 2005.

BECK, N., KATZ, J. N. What to do (and not to do) with time-series cross-section data. The American Political Science Review 89 (3), pp. 634-647, 1995.

BREU.S.CH, T. S., PAGAN, A. R. The Lagrange multiplier test and its application to model specifications in econometrics. Review of Economic Studies 47, pp. 239-53, 1980.

CFS - Center for Food Safety. Monsanto vs. U.S. Farmers: a Report by the Center for Food Safety, 2005. Available at www.centerforfoodsafety.org

CFS - Center for Food Safety. Monsanto vs. U.S. Farmers: Update, 2007. Available at www.centerforfoodsafety.org

ENDERS, A. B., GOLDSMITH, P.D. Alternative business strategies in weak intellectual property environments: A law \& economics analysis of the agro-biotechnology firm's strategic dilemma. Journal of Intellectual Property Law 14 (2), pp. 237-268, 2007.

GOLDSMITH, P. D., RAMOS, G., STEIGER, C. Intellectual property piracy in a North-South context: Empirical evidence. Agricultural Economics 35, pp. 335349, 2006.

KESAN,J. P., GALLO, A. A. Property rights and incentives to invest in seed varieties: Governmental regulations in Argentina. Agbioforum 8, pp. 118- 126, 2005.

LESSER, W. Intellectual property rights and concentration in agricultural biotechnology. AgBioForum 1(2), pp. 56-61, 1998.

MAXWELL, B. J., WILSON, W. W., DAHL, B. L. Producer contract strategies in GM crops. Agribusiness \& Applied Economics Report no 539 - Department of 
Agribusiness and Applied Economics, North Dakota State University, 2004. Available at http://ageconsearch. umn.edu/handle/23534

TEECE D. J. Profiting from technological innovation: Implications for integration, collaboration licensing and public policy. Research Policy 15, pp. 285-305, 1986.

UNCTAD - United Nations Conference on Trade and Development. Tracking the trend towards market concentration: The case of the agricultural input industry. Study prepared by the UNCTAD Secretariat, 2006. Available at www.unctad.org
WRIGHT, B. D., PARDEY, P. G. The evolving rights to intellectual property protection in the agricultural biosciences. Int. J. Technology and Globalization 2, pp. 12$29,2006$.

ZYLBERSZTAJN, D., MACHADO FILHO, C. A. P., SPERS, E. E., NOGUEIRA, A. C. L. Contracting under weak institutions: A note on illegal seed markets. Paper presented at the CONFERENCE OF THE BU.S.INESS ASSOCIATION OF LATIN AMERICAN STUDIES, San José, Costa Rica, 2007. 


\section{Appendix: Description of variables}

\section{A1. Brazil}

\begin{tabular}{|c|c|c|}
\hline Variable & Description & Source \\
\hline $\begin{array}{l}\text { Consumption of brow- } \\
\text { bagged and saved soybean } \\
\text { seed }\end{array}$ & $\begin{array}{l}\text { The variable was constructed with data from the } \\
\text { Brazilian Association of Seeds and Seedlings (Abrasem). } \\
\text { The association computes for each Brazilian state the } \\
\text { potential seed demand and the actual consumption of } \\
\text { certified seeds. The difference between these values } \\
\text { corresponds to the consumption of brown-bagged and } \\
\text { saved seed. The dependent variable is then the ratio } \\
\text { between the consumption of brown-bagged and saved } \\
\text { seeds and potential demand. }\end{array}$ & $\begin{array}{l}\text { Brazilian Association of Seeds and } \\
\text { Seedlings (Abrasem) }- \text { available at } \\
\text { www.abrasem.com.br }\end{array}$ \\
\hline $\begin{array}{l}\text { Price of certified soybean } \\
\text { seed }\end{array}$ & $\begin{array}{l}\text { Average price for soybean seed marketed in the state of } \\
\text { Sao Paulo. }\end{array}$ & $\begin{array}{l}\text { Institute of Agricultural Economics } \\
\text { (IEA) - available at www.iea.sp.gov.br }\end{array}$ \\
\hline Soybean price & $\begin{array}{l}\text { Average price received by farmers for the bag of } 60 \mathrm{~kg} \text { of } \\
\text { soybean in state of Parana. }\end{array}$ & $\begin{array}{l}\text { Secretariat of Agriculture and Supply, } \\
\text { Department of Rural Economics (Seab- } \\
\text { PR) - available at www.ipeadata.gov.br }\end{array}$ \\
\hline Glyphosate price & Average price paid by farmers for Roundup in Sao Paulo & $\begin{array}{l}\text { Institute of Agricultural Economics } \\
\text { (IEA) - available at www.iea.sp.gov.br }\end{array}$ \\
\hline Credit & $\begin{array}{l}\text { Credit operations from the public and private sectors } \\
\text { directed to the funding of the rural sector ( } \mathrm{R} \$ \text { millions). }\end{array}$ & $\begin{array}{l}\text { Brazilian Central Bank - available at } \\
\text { www.ipeadata.gov.br }\end{array}$ \\
\hline $\begin{array}{l}\text { Production region } \\
\text { (Southern region; Midwest) }\end{array}$ & \multirow{3}{*}{ dummy } & \multirow{3}{*}{ Research data } \\
\hline Introduction of GM seeds & & \\
\hline $\begin{array}{l}\text { Amendment of New } \\
\text { Biosafety Law in } 2005\end{array}$ & & \\
\hline
\end{tabular}

Source: Prepared by the authors. 
A2. U.S.

\begin{tabular}{|c|c|c|}
\hline Variable & Description & Source \\
\hline $\begin{array}{l}\text { Consumption of brow- } \\
\text { bagged and saved soybean } \\
\text { seed }\end{array}$ & $\begin{array}{l}\text { The variable was constructed with information about } \\
\text { agricultural practices in soybean production. The U.S. } \\
\text { Department of Agriculture (U.S.DA) has conducted } \\
\text { an annual survey from } 1997 \text { to } 2002 \text { (except 2001) on } \\
\text { the different practices adopted by farmers. In one } \\
\text { survey item, the researcher investigated the origin of } \\
\text { the soybean seed used by the farmer. There are two } \\
\text { classifications: commercial seed market (purchased) and } \\
\text { seeds saved or traded between producers (home grown } \\
\text { or traded). The dependent variable corresponds to the } \\
\text { ratio of (i) consumption of saved or traded between } \\
\text { producers' seed and (ii) the total consumption of seed. }\end{array}$ & $\begin{array}{l}\text { U.S.DA - available at www.ers.usda. } \\
\text { gov/data/arms/ }\end{array}$ \\
\hline Legal claims & $\begin{array}{l}\text { Cumulative legal claims brought against farmers on the } \\
\text { alleged reason of saving GM seeds. }\end{array}$ & Center for Food Safety (CFS). \\
\hline $\begin{array}{l}\text { Price of certified soybean } \\
\text { seed }\end{array}$ & Average price for soybean seed marketed in the U.S.. & $\begin{array}{l}\text { U.S.DA - avaliable at http://usda. } \\
\text { mannlib.cornell.edu }\end{array}$ \\
\hline Soybean price & $\begin{array}{l}\text { Average price received by farmers for soybeans in the } \\
\text { U.S.. }\end{array}$ & $\begin{array}{l}\text { U.S.DA - avaliable at http://usda. } \\
\text { mannlib.cornell.edu }\end{array}$ \\
\hline Glyphosate price & Average price paid by farmers for Roundup in the U.S.. & $\begin{array}{l}\text { U.S.DA - avaliable at http://usda. } \\
\text { mannlib.cornell.edu }\end{array}$ \\
\hline Soybean subsidies & $\begin{array}{l}\text { Financial amount (U.S.\$ millions) of targeted subsidies } \\
\text { to soybean producers by state. }\end{array}$ & $\begin{array}{l}\text { Environmental Working Group / Farm } \\
\text { Subsidy Database - available at http:// } \\
\text { farm.ewg.org/farm/ }\end{array}$ \\
\hline $\begin{array}{l}\text { State is a major producer of } \\
\text { soybeans } \\
\text { (dummy) }\end{array}$ & $\begin{array}{l}\text { States with annual soybean production above } 180 \\
\text { million bushels. The calculations are based on the } \\
\text { average soybean production for } 2005,2006 \text { and } 2007 \text {. }\end{array}$ & $\begin{array}{l}\text { U.S.DA - available at www.nass.usda. } \\
\text { gov }\end{array}$ \\
\hline Adoption of GM technology & Adoption of herbicide-tolerant soybeans by state. & $\begin{array}{l}\text { U.S.DA - available at www.ers.usda. } \\
\text { gov/Data/BiotechCrops }\end{array}$ \\
\hline
\end{tabular}

Source: Prepared by the authors. 